\title{
特集／薬物動態
}

\section{5. 臓器移植患者における個別化免疫抑制療法}

\author{
京都大学医学部附属病院薬剤部 \\ 增 田智先乾賢一
}

\section{1.はじめに}

近年，末期藏器不全患者に対する治療の選択肢とし て「藏器移植」が取り入れられ，着実に成果を上げ, 社会的にも評価されている。移植蔵器は本来「他」で あることから，その由来が一卵性双生児でない限り， 拒絶反応を抑制するための免疫抑制剤を中心とした術 後管理は必須である.

Tacrolimus (FK 506) p cyclosporine (ciclosporin）などのカルシニューリン阻害薬は, これ までの azathioprine などを用いて行われてきた術後 管理の成績を大幅に改善するとともに, 臓器移植治療 そのものの社会的認知度の向上に大きく貢献してき た. しかし，いずれの薬物も微量で強力な薬理効果を 発揮する反面, 狭い有効治療域を有することから, 至 適投与量設定を目的とした血中濃度モニタリング (TDM) が必要とされている.一方, 頻回の TDM による血中濃度コントロールが実施されているにもか かわらず, 予後に直接影響する拒絶反応の発現, 感染 症の合併や重篤な副作用（中枢毒性, 腎毒性, 高血 糖, 高カリウム血症）を回避できない場合がある ${ }^{1)}$. 最近, 腎臓移植患者に対する cyclosporine の投与設 計は，従来の trough（C0）モニタリングではなく $\mathrm{C} 2$ (投与後 2 時間值) モニタリングのほうが適当であ るという報告もなされ, 薬物を中心とした免疫抑制療 法は移植藏器や薬剤に応じて細分化されつつある2). 本稿では, tacrolimusを中心に我々の臨床現場での 取組みも含め, 臓器移植患者に対する免疫抑制剤の適 性使用について紹介する。

\section{2. 免疫抑制剤の TDM と使用法の多様化}

強力なカルシニューリン阻害薬である tacrolimus と cyclosporine は, 化学構造上, 全く異なるにも関

₹ 606-8507 京都市左京区聖護院川原町 54
わらず，薬物動態特性が類似している. 現在, tacrolimusによる免疫抑制効果は血中濃度-時間下面積 (AUC) に相関すると考えられ，AUC と相関する trough 值をモニタリングの対象としている. Cyclosporine についても同様の考えで, trough モニ タリングの有用性が副作用防止という観点からは報告 されてきた。しかし，免疫抑制効果に対応する AUC と trough 值との相関については根拠がそしかった。 また，腎臓移植患者において cyclosporineのカルシ ニューリン阻害作用は, 血中濃度と対応することが示 されており，trough モニタリングでは不十分である と考えられる ${ }^{3)}$.これらの改善を目指した投与 12 時 間までの $\mathrm{AUC}_{0-12}$ モニタリングは, 精密ではあるも のの採血ポイントの多さから実用性に乏しい2). 2000 年に登場したマイクロエマルジョン化製剤 Neoral ${ }^{\mathrm{TM}}$ は, Sandimmun ${ }^{\mathrm{TM}}$ で認められた吸収過程に及ぼす胆 汁酸や食事の影響回避を狙ったものであり，速やかな 吸収と個体内変動の縮小に貢献している。すずに腎臓 移植治療では, cyclosporine の吸収相を示す投与後 4 時間までの $\mathrm{AUC}_{0-4}$ に相関する $\mathrm{C} 2$ 值と, 拒絶反応発 現との良好な逆相関が報告されている4). 一方, 最高 血中濃度を示す経口投与後の時間 $\left(\mathrm{T}_{\max }\right)$ の個人差 が見い出されており，C2 モニタリングの普遍性につ いては, 一定の考慮が必要かもしれない.

\section{3. 母集団薬物速度論 $(\mathrm{PPK})$ を利用した tacrolimus の個別化投与設計}

Tacrolimus の有効治療域は 5〜20 ng/mL とされ ているが, 実際の治療においては術後経過日数および 患者個々の容態に応じて，より狭い範囲にコントロー ルされる，京都大学では，生体肝移植患者に対する tacrolimus の TDM として, 術直後 1 週間程度は $10 \sim 15 \mathrm{ng} / \mathrm{mL}$ ，以降 3 週間程度までは $10 \mathrm{ng} / \mathrm{mL}$ 前 後, 退院間近になると $5 \sim 10 \mathrm{ng} / \mathrm{mL}$ というように目 標域の漸減を行っている。したがって，一般に 4 倍と 
考えられている有効治療域の幅（下限と上限の差） は, 実際の治療においては 2 倍以内と極めて狭い.こ のために, tacrolimusについては当日朝の trough 值 を参考に次回投与量を決定するという投与設計が行わ れている。一方，頻回の TDM は採血に伴う患者へ の侵襲や測定に係る医療コスト高など，医療現場で問 題となる場合がある。したがって，患者一人ひとりに おける tacrolimus の全身クリアランスをその個体内 変動を含め精密に予測できれば，医療費の節約や採血 回数の低減など，患者の QOL 向上に資することが期 待される。

これらの観点から，京都大学における胆道閉鎖症を 中心とした小児生体肝移植患者を対象に PPK 解析を 実施した結果，tacrolimusの全身クリアランスは患 者の体重および術後経過日数に影響を受けることが示 され，小児患者に対する投与設計の応用が図られてい る).

近年, 肝右葉切除の安全性が確認され, 肝臟癌を含 めた成人肝不全患者に対する生体部分肝移植の施行も 増えつつある ${ }^{6)}$. 一方，移植肝重量が体重の $3 \%$ 前後 となる小児患者と比較して，成人患者に対する移植肝 重量の確保は困難であり，体重の $1 \%$ 程度となる場合 が多(7).さらに, 術後経過に伴って肝組織の増殖・ 再生による機能回復の程度が小児患者と異なることが 臨床経験上認められ, 成人患者への小児 $\mathrm{PPK}$ パラ メータの応用は困難と予想された．京都大学での成人 生体肝移植患者 35 例を対象に PPK パラメー夕を算 出したところ，成人患者における tacrolimus の全身 クリアランスは体重や術後経過日数だけでなく，移 植肝重量, 総ビリルビン值および血清クレアチニン 值にも影響を受けることが明らかとなった (Table 1)。また，この成人 PPK パラメータは欧米 の脳死全肝移植患者で得られたものと比較して, 日本 人生体部分肝移植患者の tacrolimus 薬物動態を精度 よく反映することが示された．本成人 PPK パラメー タにベイズの定理を組合せた入院患者に対する tacrolimus の個別投与設計は, 移植後 2 週間以降の血 中濃度に対して良好な予測性を示した。したがって， 術後 2 週間以降については, PPK パラメータを用い た tacrolimus のクリアランス予測が可能となり，こ のことは結果的に採血回数の減少と血中濃度測定費用 の削減に貢献できると考える。

\section{4. 免疫抑制剤の薬物動態制御因子}

生体に投与された tacrolimus や cyclosporine は,
Table 1 成人生体肝移植患者 82 例より求めた tacrolimus の PPK パラメータ

\begin{tabular}{ccc}
\hline パラメータ & PPK 平均值 & $95 \%$ 信頼区間 \\
\hline Fixed effects $^{\mathrm{a}}$ & & \\
$\theta_{1}(\mathrm{~L} / \mathrm{hr})$ & 0.743 & $0.561 \sim 0.925$ \\
$\theta_{2}(\mathrm{~L} / \mathrm{kg})$ & 1.64 & $1.48 \sim 1.80$ \\
$\theta_{3}$ & 0.0732 & $0.0565 \sim 0.0899$ \\
$\theta_{4}$ & 0.792 & $0.639 \sim 0.945$ \\
$\theta_{5}(\mathrm{~L} / \mathrm{hr} /$ day $)$ & 0.0157 & $0.0032 \sim 0.0282$ \\
$\theta_{6}$ & 0.810 & $0.694 \sim 0.926$ \\
Random effects & & \\
$\omega_{\mathrm{CL}}(\%)$ & 60.0 & $48.8 \sim 69.6$ \\
$\omega_{\mathrm{V}}(\%)$ & 35.4 & $28.6 \sim 41.0$ \\
$\omega_{\mathrm{F}}(\%)$ & 71.2 & $52.9 \sim 85.7$ \\
$\rho(\mathrm{CL}, \mathrm{F})$ & 0.770 & 推定不可 \\
$\sigma(\mathrm{ng} / \mathrm{mL})$ & 2.57 & $2.35 \sim 2.77$ \\
\hline
\end{tabular}

$\mathrm{a}: \theta_{\mathrm{n}}$ はモデル式 $\mathrm{CL}=\left(\theta_{1}+\theta_{5} * \mathrm{POD}\right) * \theta_{4}{ }^{\mathrm{HF}} * \theta_{6}{ }^{\mathrm{RF}} *$ $\mathrm{HW} / 600, \mathrm{~V}=\theta_{2} * \mathrm{BW}$ and $\mathrm{F}=\theta_{3}$ より求めた. なお, 総ビリルビン值が $2.5 \mathrm{mg} / \mathrm{dL}$ 以上の場合は $\mathrm{HF}=1$, 未満の場合は $\mathrm{HF}=0$. 血清クレアチニン值が $1 \mathrm{mg} / \mathrm{dL}$ 以上の場合は $\mathrm{RF}=1$, 未満の場合は $\mathrm{RF}=0$.

主として肝藏に発現する薬物代謝酵素チトクロム P450 IIIA4（CYP3A4）によって代謝されること， 代謝物および未変化体薬物は引き続き $\mathrm{P}$ 糖蛋白質 （Pgp，MDR1 遺伝子にコードされる）を介して胆汁 中に排泄されることが知られている。 また，CYP3A4 やPgp は小腸粘膜にも発現しており，経口投与され たこれら薬物の吸収過程における代謝・排泄を媒介す ることによって，薬物の吸収障壁として協働的に機能 することから，経口投与された免疫抑制剤の血中濃度 を支配する重要な生体因子として位置づけられてい る ${ }^{10)}$. したがって，小腸の Pgp や CYP3A4 の同一患 者における発現変動や個人差に関する情報は，これら 免疫抑制剂の個別投与設計を行ううえで有用な指標に なると考えられる。

また，tacrolimusや cyclosporine はそれぞれ FK 506-binding protein (FKBP) またはcyclophilin と 複合体を形成し, 標的蛋白質であるカルシニューリン の脱リン酸化活性を阻害する。したがって，これら結 合蛋白質は免疫抑制剂に対する感受性の個人差を規定 すると考えられる.しかし，これら蛋白質の遺伝的・ 量的差異に関わる明確な指標はいまだ見い出されてお らず，これら遺伝子を含め種々ゲノム情報を利用した 薬物感受性予測マーカーの特定と, 有効血中濃度の個 別化が望まれる。 
Table 2 生体肝移植患者における小腸吸収障壁の発現レベルが及ぼす tacrolimus の薬物動態の影響

\begin{tabular}{lccr}
\hline \multicolumn{1}{c}{ カテゴリー } & High & Low & $P$ 值 \\
\hline MDRI mRNA 発現量で分類した場合 & & & \\
& $\mathrm{n}=102$ & $\mathrm{n}=99$ & \\
経口投与量 (mg/kg/day) & $0.13 \pm 0.01$ & $0.07 \pm 0.01$ & $<0.001$ \\
tacrolimus の trough 值 $(\mathrm{ng} / \mathrm{mL})$ & $11.5 \pm 0.58$ & $11.0 \pm 0.52$ & 0.476 \\
C/D*比 & $143.8 \pm 18.2$ & $230.1 \pm 20.9$ & 0.002 \\
\hline CYP3A4 mRNA 発現量で分類した場合 & & & \\
& $\mathrm{n}=96$ & $\mathrm{n}=105$ & \\
経口投与量 (mg/kg/day) & $0.10 \pm 0.01$ & $0.10 \pm 0.01$ & 0.857 \\
tacrolimus の trough 值 $(\mathrm{ng} / \mathrm{mL})$ & $12.1 \pm 0.60$ & $10.5 \pm 0.49$ & 0.042 \\
\hline
\end{tabular}

* : C/D, tacrolimus $の$ trough 值/前日の経口投与量

\section{5. 生体肝移植患者における薬物動態 制御因子の役割と臨床応用}

生体肝移植術では，患者の小腸を一部用いて移植肝 から流れ出る胆汁を通すための胆管再建を行う場合が ある. 我々は，このときに切除される小腸組織片の一 部を用いて小腸上皮細胞に発現する Pgp および CYP 3A4 の発現量を定量し, 術後の tacrolimus 体内動態 との相関解析を行った。その結果，術直後一定の tacrolimus 血中濃度を得るためにMDR1 高発現群で は，MDR1 低発現群と比較して約 2 倍の tacrolimus 投与量を必要とすること，すなわち小腸 Pgp 発現量 は tacrolimus 体内動態に大きく影響することが明ら かとなった ${ }^{11)}$ (Table 2)。また，慢性拒絶反応による 再移植例において，小腸 Pgp 発現の上昇に伴う術後 の cyclosporine 吸収不良例を経験した ${ }^{12)}$ ，本症例で は，慢性拒絶反応に加え慢性的な胆管炎も合併してお り，さまざまな臨床症状が小腸の Pgp 発現を変化さ せること，肝機能が低下した場合には小腸 Pgp を介 した免疫抑制剂の小腸管腔中への back flux の影響が 大きくなることが示唆された. 生体肝移植治療に用い られる移植肝は部分肝であり，そのサイズは移植後， 経日的に回復する ${ }^{13)}$. Tacrolimus の体内動態につい ても経日的な全身クリアランスの増大を認めるが8), 術後初期における有用な投与量設定のための指標が不 明であった．以上の結果から，術後初期においては移 植肝の機能レベルが低く，小腸 Pgp の発現量が tacrolimus 投与量設定マーカーになると考えられた。 現在我々は，術時小腸組織を用いたMDR1 mRNA の定量数值化とそれに基づく tacrolimus の初期投与 量設定を継続しており，一定の成果を上げつつある。 一方，良好な小腸 Pgp 発現量と tacrolimusの trough 值/前日の投与量（C/D）比の相関関係は，術 後 10 日以降乘離し始める.この原因として, 術後の 経時的な肝機能の回復（肝重量の増加）とそれに伴う 肝クリアランスの増大があげられる。したがって，術 後 2 週間以降は先に述べた PPK とベイジアン解析に よる tacrolimus の個別投与設計が，免疫抑制療法の 個別化に貢献すると考えられる。

\section{6. 小腸移植患者における薬物動態 制御因子の役割と臨床応用}

生体小腸移植症例についても同様の解析を行ったと ころ, 小腸 Pgp の発現量変動は tacrolimus 体内動態 の個体内変動に大きく影響することが示された ${ }^{14)}$.と

くに，術後早期ならびに拒絶反応からの回復過程にお いては小腸 Pgp の発現量が大きく変動するため，静 注を中心とした tacrolimus 血中濃度のコントロール が有効であること，小腸 Pgp の発現量が安定した時 点で経口のみに変更することが合理的であることが示 唆された。これらの結果を基に，以降実施された 2 例 の小腸移植患者について，移植小腸生検組織の一部を 用いたPgp 発現レベル定量とそれに基づく tacrolimus 投与設計を試みたところ，少なくとも術後 50 日間における良好な tacrolimus 血中濃度コント ロールが可能となった．以上の結果は，小腸 Pgp 発 現量が小腸移植患者においても tacrolimus 投与設計 の個別化に重要な役割を担うことを示している.

\section{MDR1 遺伝子多型情報の免疫 抑制療法への応用の可能性}

これまで述べてきたように，肝臓移植患者ならびに 小腸移植患者に対する小腸 Pgp 発現レベルは，術後 の tacrolimus または cyclosporine を中心とした免疫 
抑制療法を円滑に行ううえで有用であると考えられ た. 最近, Pgpの基質薬物の動態特性が， MDR 1 遺 伝子多型によって影響を受けることが報告されてい る ${ }^{15)}$.したがって，小腸 Pgp の発現量に影響を与え る遺伝子多型を見い出すことができれば，患者一人ひ とりの小腸組織を採取・解析するまでもなく，初期投 与量を設定することが可能になる。しかし，小腸 Pgp の発現量や機能に影響を及ぼすと考えられてい る MDR1 mRNA の C3435T 多型は, 生体肝移植患 者の小腸 Pgp 発現量や術後初期の tacrolimus 動態に 対して有意な影響を示さなかった。また，MDR1 遺 伝子の C3435T 多型は, 小腸 CYP3A4 発現量と有意 な相関性を示し，本多型が $C Y P 3 A 4$ 遺伝子上の小腸 CYP3A4 発現量に影響を及ほす未知の多型と連鎖し ている可能性が示唆された ${ }^{16)}$.

\section{8.おわりに}

免疫抑制を目的として使用される薬物は, 臓器移植 医療分野のみならず膠原病など自己免疫疾患の領域で も広く使用されている．わが国において，腎藏や肝臓 に代表される臟器移植治療で使用される免疫抑制剤 は, steroid剂, azathioprine, tacrolimus, cyclosporine および mycophenolate mofetil (MMF) や，抗体医薬品として抗 CD3 モノクローナ ル抗体 (muromonab-CD3) および抗 CD25 モノク ローナル抗体（basiliximab）などがある. 最近で は，抗 CD25 モノクローナル抗体 (daclizumab) や rapamycin（silolimus）など，本邦でいまだ承認を 受けていない薬物の試用とそれらを用いた予後成績が 報告されつつあり興味深い. 臟器移植後の免疫抑制療 法としてまとめられてきた時代から，多様化する時代 へと，今後，ますます個別化免疫抑制療法の必要性は 高まるであろう。それぞれの原疾患, 移植㵴器, 患者 背景, 術後経過, 薬物感受性および動態特性に応じた 個別化が期待される。

\section{文献}

1) Venkataramanan R, Swaminathan A, Prasad T, Jain A, Zuckerman S, Warty V, McMichael J, Lever J, Burckart G, Starzl T. Clinical pharmacokinetics of tacrolimus. Clin Pharmacokinet $1995 ; 29: 404-30$.

2) Lindholm $A$, Kahan BD. Influence of cyclosporine pharmacokinetics, trough concentrations, and AUC monitoring on outcome after kidney transplantation. Clin Pharmacol Ther $1993 ; \mathbf{5 4}: 205-18$.

3) Kelles A, Herman J, Tjandra MT, Van D, Lombaerts R. Sandimmune to Neoral conversion and value of abbreviated AUC monitoring in stable pediatric kidney transplant recipients. Pediatr Transplant $1999 ; 3: 282-7$.

4) Levy GA. C2 monitoring strategy for optimising cyclosporin immunosuppression from the Neoral formulation. Bio Drugs $2001 ; 15: 279-90$.

5) Yasuhara M, Hashida T, Toraguchi $M$, Hashimoto $Y$, Kimura $\mathrm{M}$, Inui $\mathrm{K}$, Hori $\mathrm{R}$, Inomata $\mathrm{Y}$, Tanaka $\mathrm{K}$, Yamaoka $\mathrm{Y}$. Pharmacokinetics and pharmacodynamics of FK506 in pediatric patients receiving living-related donor liver transplantations. Transplant Proc $1995 ; 27: 1108-10$.

6) Inomata $Y$, Uemoto $S$, Asonuma $K$, Egawa $H$, Kiuchi $T$, Fujita S, Hayashi M, Kawashima M, Tanaka K. Right lobe graft in living donor liver transplantation. Transplantation $2000 ; 69: 258-64$.

7) Kiuchi $T$, Inomata $Y$, Uemoto $S$, Asonuma $K$, Egawa $H$, Hayashi M, Fujita S, Tanaka K. Living-donor liver transplantation in Kyoto, 1997. Clin Transpl $1997 ; 18: 191-8$.

8) Fukatsu S, Yano I, Igarashi $T$, Hashida $T$, Takayanagi $K$, Saito H, Uemoto S, Kiuchi T, Tanaka K, Inui K. Population pharmacokinetics of tacrolimus in adult recipients receiving living-donor liver transplantation. Eur J Clin Pharmacol $2001 ; \mathbf{5 7}:$ 479-84.

9) Fukudo M, Yano I, Fukatsu S, Saito H, Uemoto S, Kiuchi T, Tanaka K, Inui K. Forecasting of blood tacrolimus concentrations based on the Bayesian method in adult patients receiving living-donor liver transplantation. Clin Pharmacokinet 2003. (in press)

10) Patel J, Mitra AK. Strategies to overcome simultaneous P-glycoprotein mediated efflux and CYP3A4 mediated metabolism of drugs. Pharmacogenomics $2001 ; 2: 401-15$.

11) Hashida $T$, Masuda $S$, Uemoto $S$, Saito $H$, Tanaka $K$, Inui $K$. Pharmacokinetic and prognostic significance of intestinal MDR1 expression in recipients of living-donor liver transplantation. Clin Pharmacol Ther 2001 ; 69 : 308-16.

12) Masuda $S$, Goto $M$, Kiuchi $T$, Uemoto $S$, Kodawara $T$, Saito H, Tanaka K, Inui K. Enhanced expression of enterocyte P-glycoprotein depresses cyclosporine bioavailability in a recipient of living-donor liver transplantation. Liver Transpl 2003. (in press)

13) Kawasaki S, Makuuchi M, Ishizone $\mathrm{S}$, Matsunami $\mathrm{H}$, Terada $\mathrm{M}$, Kawarazaki $\mathrm{H}$. Liver regeneration in recipients and donors after transplantation. Lancet $1992 ; 339: 580-1$.

14) Masuda $S$, Uemoto $S$, Hashida $T$, Inomata $Y$, Tanaka $K$, Inui K. Effect of intestinal P-glycoprotein on daily tacrolimus trough level in a living-donor small bowel recipient. Clin Pharmacol Ther 2000; 68: 98-103.

15) Fromm MF. The influence of MDR1 polymorphisms on P-glycoprotein expression and function in humans. Adv Drug Deliv Rev $2002 ; 54: 1295-310$.

16) Goto M, Masuda $S$, Saito $H$, Uemoto $S$, Kiuchi $T$, Tanaka $K$, Inui K. C3435T polymorphism in the MDR 1 gene affects the enterocyte expression level of CYP3A4 rather than Pgp in recipients of living-donor liver transplantation. Pharmacogenetics $2002 ; 12: 451-7$. 